\title{
施工者からみた外壁ラス下地モルタル塗り仕上げの現状の研究 RESEARCH ON AND PRESENT CONDITIONS OF MORTAR COATING FINISH OF EXTERNAL WALL WITH LATH ON SITFROM THE VIEW POINT OF A PLASTERER
}

鈴木 光*, 吉田倬郎**, 三原 斉***

\section{Ko SUZUKI, Takuro YOSHIDA and Hitoshi MIHARA}

\author{
The following became clear as the result of investigation of mortar coating finish of external wall with lath on site. \\ 1. Inapplicable waterproof paper which is not shown on JASS 15 is used nationwide. \\ 2. It is recognized that flat lath is used nationwide. \\ 3. It is recognized that inapplicable staple is used in all areas. \\ 4. Lightening of mortar has improeed, but it is recognized that light weight mortar as existing compounding does not yet spread \\ the whole country.
}

As a result of investigation, at the time of an earthquake of detaching and exfoliating external wall of lath mortar are concerned about.

Keywords : $\quad$ plasterer, JASS 15, external wall, lath, mortar, history

左官, JASS 15, 外壁, ラス, モルタル, 歴史

\section{1. はじめに}

外壁ラス下地モルタル塗り仕上げについては、JASS 15 (左官工事)

1) 等に示された仕様による施工が、地震時に剥離・剥落安全性や耐震 安全性の確保に寄与寸ることが、既往の研究 2,3.4,5) により明らかと なっている。しかし、材料選択や施工等が不適切な場合は、地震時に、 ラスモルタルが剥落し、これに続き下地材等が露出することになる。 これは、類焼・延焼の要因となり得る。特に、宮城県沖地震 (1979) 以前の規準に基づいて造られた、あるいは、JASS 15 （1998）の規準 に満たない構工法の場合に、剥離・剥落事象を生じることが、中越 地震等の調查結果によって明らかになっている。

剥離・剥落の安全性対策のみならず、（独）住宅金融支援機構の 仕様書 ${ }^{7)}$ や住宅瑕疪担保責任保険法人の全保険法人で統一された仕 様書 ${ }^{8)}$ には、雨漏り対策も明記され、JASS 15 を含め外壁ラス下地 モルタル塗り仕上げの仕様が確立されている。しかしながら、外壁 ラス下地モルタル塗り仕上げに、現在使用される材料・部材は、過 去からの経験に基づいているものが多くあり、JASS 15 等の仕様と 乘離が見られる。著者らは乘離の実態を明らかにするために、過去 からの経験的に使用されてきた材料・部材の変遷を確認した。さら に外壁ラス下地モルタル塗り仕上げが、確立された JASS 15 に定め られた施工で実際行なわれているか、現在の施工実態についてアン ケート調査を行った。各材料・部材の評価の一部は、著者が参画す る共同研究の成果を示している。本研究は、現在の構工法の実態を
調查に基づいて明らかにし、JASS 15（2007）と現状の相違について 考察し、これを踏まえ、JASS 15 に示している外壁ラス下地モルタ ル塗り仕上げの一層の普及の方向を示すことを目的とした。

\section{2. 外壁ラス下地モルタル仕様の調査の概要}

外壁ラス下地モルタル壁の剥離・剥落性は、使用寸る材料や接合具 および施工方法に影響される。JASS 15 には、それぞれが伴う要求 品質を確保する施工方法が、既往の研究に基づき反映されているが、 基礎データや評価方法がまだ、充分に整備されていないとされる。 また、実務面で、その構工法の選択に際しては、価格および施工性 が優先されてきた。このように多くの問題点がある現状を踏まえて、 著者らは、社団法人日本左官業組合連合会（以下「日左連」）の会員 の協力により、改めて、全国的に外壁ラス下地モルタル塗り仕上げ の施工実態についてアンケート調查を実施した。

日左連は、10の地域団体で構成されており、これらの団体単位で 調査の取り纏めを行うことにした。調査票は、組合員のいない奈良県 を除いた全国 46 都道府県を対象に 545 通を発送し、246 通の回答を 得た。モルタル外壁が普及している地区や大都市圈には、調查票を増 やしている。調査票の発送と回答の状況を、表 1 に示す。表は地域 区分と都道府県の関係を示し、また、発送数、回答数、回答率を県 連ごとに示している。回答者の属性は、アンケート表にあらかじめ 示した選択肢の中の該当するものに○を付けてもらっている。回答

\footnotetext{
* 鈴木建塗工業侏 $)$ 修士 (工学)

** 工学院大学工学部建築学科 教授. 工博 Suzuki Kentokogyo Co., Ltd.

***ものつくり大学 教授・博士 (工学) 
者の属性の割合は、代表者 $(71.4 \%)$ 、会社幹部（10.1\%）、事務 職 $(0.8 \%)$ 、左官技能者 $(27.3 \%)$ 、ラス専門職 $(4.2 \%)$ 、その 他 $(0.4 \%)$ であった。

アンケート調査の質問は Q1 から Q9 で、以下に示すとおりである。 Q1：外壁にモルタルを塗る場合の下地及びラスはどのような施工 か?

Q2：ラス下地板の寸き間の間隔は、どの程度の幅か？

Q3 : 防水紙（フェルト）は、なにを使用しているか?（商品名でも 可)

Q4：防水紙（フェルト）の張る方向は?

Q5：使用しているラスは? ・その施工割合は？（全体を 100\%)

Q6 : ラスの張る方向は?

Q7 : 使用しているタッカー釷 (ステープル) は? ・その施工割合は? （全体を 100\%)

Q8：タッカー釘（ステープル）留め付け間隔は?

Q9：使用しているモルタルは？（全体で 100\%）

表1モルタル外壁の仕様調査の発送と回答の状況
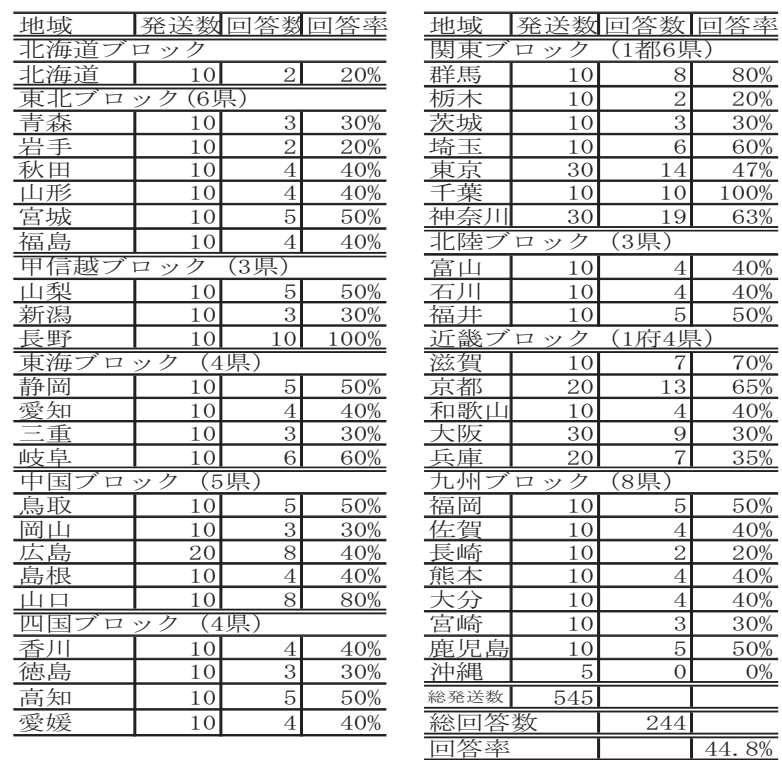

\section{3. 下地材とラスの歴史と仕様の調査結果}

\section{1 現在の外壁左官仕上げにつながるラス下地構法の変遷}

我が国の外壁左官仕上げでの幕末期以降の変遷は、次のように要 約できる。幕末期には、軸組にまず木摺を打ち、その上に下地平瓦 を張り、漆喰を塗り仕上げた。時期は不明であるが、その後、瓦下 地にセメントモルタルを塗るようになる。（表 2）また、軸組に木 摺を打ち、その上に鉄網（表 3）あるいはメタルラスを張り（表 4） セメントモルタルを塗り仕上げにする工法が、今日の外壁ラス下地 モルタル仕上げとなる。 ${ }^{9)}$ 表 $2 \cdot 3 \cdot 4$ は「左官の知識及彫刻手引」注1) 「プラスター誌」注 2) にある記述より、明治以後におけるラス下地 モルタル構法の変遷の概要を示したものである。表 $2 \cdot 3 \cdot 4$ の表側に ある『モルタル塗り』には、それぞれ下塗り、中塗り、上塗りの工 程があったことが読み取れる。
表2 左官文献にみる縦瓦壁の工法

\begin{tabular}{|c|c|}
\hline 瓦の下地 & $\begin{array}{l}\text { 柱の表面に松赤みの大貫を筋違いまたは横に打ち付ける。その釘 } \\
\text { に棕㯗毛、麻を } 1 \text { 尺 } 5 \text { 地りだておく。 } \\
\end{array}$ \\
\hline 瓦材料 ·工法 & \begin{tabular}{|l|l} 
大きさ約 $30 \mathrm{~cm}$ 角、厚さ 6 から 7 分に四隅に釷穴のある平瓦を带 \\
鉛引き鉄釘または銅の 3 寸釘で張る。 \\
\end{tabular} \\
\hline モルタル塗り & 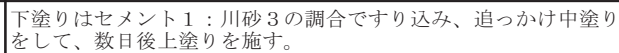 \\
\hline
\end{tabular}

表3 左官文献にみる臀䈴壁の工法

\begin{tabular}{|c|c|}
\hline 臀䈴 & 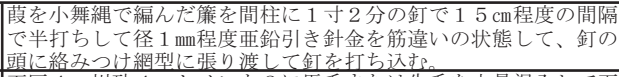 \\
\hline モルタル塗り & 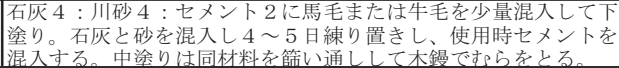 \\
\hline
\end{tabular}

\begin{tabular}{|c|c|}
\hline ラス下地板 & 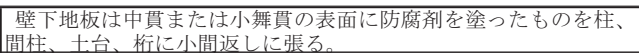 \\
\hline 防水紙材料 & フェルトを水分が侵入しないように張込む。 \\
\hline メタルラス & 26 番（（４５０㚙）以上の鉄板を用いたものにエナメルを塗る。 \\
\hline ステープル & 12 ミリから 24 沙の釷を $30 \mathrm{~cm}$ 間隔に打ち付ける。 \\
\hline モルタル塗り & 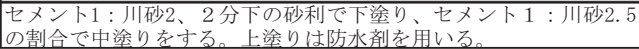 \\
\hline
\end{tabular}

\section{2 下地材とラスの仕様の現状}

アンケート調査の質問のうち、下地材とラスの仕様の施工実態に 関するのは、Q 1、Q2 である。表 5 は Q1 の『外壁ラスモルタルを 塗る場合の下地材とラスの仕様』の調査結果を示す。

表 6 は、Q2 の『ラス下地板のすき間の間隔』の調査結果を示す。 表 5 の下地板とラスの組み合わせの 7 項目は、アンケート票にあら かじめ選択肢として示し、該当するものに○を付けてもらっている。

表5 外壁ラスモルタルを塗る場合の下地材とラスの仕様

\begin{tabular}{|c|c|c|c|c|c|c|c|c|}
\hline & $\begin{array}{c}\text { ラス下地板 } \\
\text { +平ラス }\end{array}$ & $\begin{array}{l}\text { 面材+ } \\
\text { 平ラス }\end{array}$ & $\begin{array}{l}\text { ラス下地板 } \\
+ \text { +波形ラス }\end{array}$ & $\begin{array}{c}\text { 面材+波 } \\
\text { 形ラス }\end{array}$ & $\begin{array}{c}\text { 胴緣+紙 } \\
\text { 付き今不 } \\
\text { (通気構 } \\
\text { 法) } \\
\end{array}$ & $\begin{array}{l}\text { インラ } \\
\text { スエ法 }\end{array}$ & |特殊ラ & 計 \\
\hline 北海道·東北 & $42.5 \%$ & $16.3 \%$ & $10.2 \%$ & $13.0 \%$ & $5.7 \%$ & $4.1 \%$ & $8.2 \%$ & $100.0 \%$ \\
\hline 東京を除く関東 & $18.0 \%$ & $7.5 \%$ & $26.6 \%$ & $33.0 \%$ & $8.0 \%$ & $4.3 \%$ & $2.5 \%$ & $100.0 \%$ \\
\hline 甲信越·北陸 & $54.4 \%$ & $16.2 \%$ & $12.7 \%$ & $3.8 \%$ & $5.5 \%$ & $6.6 \%$ & $0.8 \%$ & $100.0 \%$ \\
\hline 東海 & $33.7 \%$ & $16.1 \%$ & $13.3 \%$ & $14.4 \%$ & $2.5 \%$ & $13.6 \%$ & $6.4 \%$ & $100.0 \%$ \\
\hline 近畿 & $40.4 \%$ & $23.1 \%$ & $9.6 \%$ & $1.6 \%$ & $5.6 \%$ & $8.7 \%$ & $11.1 \%$ & $100.0 \%$ \\
\hline 中国·四国 & $54.3 \%$ & $9.4 \%$ & $7.8 \%$ & $6.0 \%$ & $7.4 \%$ & $7.0 \%$ & $8.1 \%$ & $100.0 \%$ \\
\hline 九州 & $76.3 \%$ & $4.8 \%$ & $7.0 \%$ & $0.0 \%$ & $4.8 \%$ & $4.7 \%$ & $2.3 \%$ & $100.0 \%$ \\
\hline 東京 & $5.2 \%$ & $13.8 \%$ & $9.6 \%$ & $52.9 \%$ & $6.4 \%$ & $5.0 \%$ & $7.1 \%$ & $100.0 \%$ \\
\hline 全国 & |40.7\% & 13.4\% & $12.0 \%$ & 15.6\% & 5.7\% & $6.8 \%$ & $5.8 \%$ & $100.0 \%$ \\
\hline
\end{tabular}

表 5 に示す下地板とラスの組み合わせ構成する材料の仕様を、(1) 〜 (5)に示す。

(1) ラス下地板

一般に乾燥した杉板で断面寸法 $12 \mathrm{~mm} \times 75 \mathrm{~mm}$ 用いたものである。

(2) 面材下地

ここでいう面材下地とは、主に合板を用いた下地を意味する。 (3)胴縁紙付きラス

通気構法の単層下地に用いるものである。防水紙とラスが一体に なっている。

(4)ノンラス下地

ラス系下地に対してラスを用いないでセメントモルタルとの接着 を確保したものである。一般にメーカー仕様の構工法になる。

(5)特殊ラス

JASS 15 でいう、力骨付き平ラス、ラスシート等を指す。

ラス下地板のすき間の間隔については、表 6 に示す 7 区分をア ンケート表に示し、回答者に選択してもらっている。

表6 ラス下地板のすき間の間隔（mm） \begin{tabular}{l|l|l|l|l|l|l|}
\hline $5 \mathrm{~mm}$ 以内 & $6 \sim 10$ & $11 \sim 15$ & $16 \sim 20$ & $21 \sim 25$ & $26 \sim 30$ & $30 \mathrm{~mm}$ 以上 \\
\hline
\end{tabular} \begin{tabular}{l|l|l|l|l|l|l|}
$9.9 \%$ & $27.9 \%$ & $20.7 \%$ & $14.9 \%$ & $10.4 \%$ & $9.5 \%$ & $6.8 \%$ \\
\hline
\end{tabular} 


\section{3 下地材料のまとめ}

表 5 から以下のことが読みとれる。まず、(1)のラス下地板は 2 種 類のラスとの組み合わせを合わせて $50 \%$ を超えている。そのうち、 全国の平均で、ラス下地板の上に平ラスを留め付ける構法が最も多 く、40.7\%となった。(2)の面材下地は、関東及びその周辺で多く、ラ スは波形ラスが用いられている。そこから離れた地域では、ラス下 地板十平ラスの組み合わせが多い。都市部で波形ラス使用割合が高 いことの背景には、施工者に対して設計監理や製造者の指導がある ことが推測できる。

表6から以下のことが読みとれる。まず、ラス下地板のすき間の 間隔は、全国の平均で6〜 $10 \mathrm{~mm}$ が最も多かった。しかし、 $5 \mathrm{~mm}$ 以内か ら $30 \mathrm{~mm}$ 以上とすき間の間隔が、ばらつきの大きいこともわかる。こ れには、JASS 11 (木工事) やJASS 15 (左官工事) で、ラス下地板 ですき間の間隔の仕様が示されてないことも、影響していると考え られる。「平成 16 年新潟県中越地震における湿式外壁被害調査」 (その 2 ラスモルタルおよび土壁の被害調査)によるとラス下地板 ですき間の間隔が大きいためラスモルタルの剥落事例がある。6)

JASS に定めるラス下地の区分は、JASS 11 (木工事) に示されて おり、ラス下地板の寸き間の間隔が標準化されていない現状にある。 11) JASS 15に示さているラス下地板は断面寸法 $12 \mathrm{~mm} \times 75 \mathrm{~mm}$ を標準と している。ラス下地板の断面寸法を考慮すると、ステープル間隔が JASS 15で100mm間隔以内としていることから、ラス下地板の寸き間 の間隔は、 $25 \mathrm{~mm}$ 間隔であると考えられる。

\section{4. 防水紙材料の仕様の調査結果}

\section{1 防水紙材料の変遷}

1901 年（明治 34 年）に水田有義が『紙瓦』で特許を取得し、さ らに同年、東京板紙㑣がこけら板の代用としての『土居莫紙』で特 許を取得している。1913 年（大正 2 年）に日本建築用紙株式会社が 『便利瓦』の生産を開始した。関東大震災後アスファルトルーフィ ングは都市復興に大量に用いられ、需要を伸ばしてきたが、第二次 大戦時に石油不足で生産を停止した。その後はそれに代わるタール フェルトが用いられてきた。1950 年 (昭和 25 年) には、石油輸入 再開でアスファルトフェルトが防水紙として一般化された。11)

1957 年（昭和 32 年）には、JIS の規格として JIS A 6005 (アスフ アルトフェルト) JIS A 6006 (アスファルトルーフィング)及び JIS A 6007 (砂付きルーフィング)が制定された。

1991 年 (平成 3 年) には、3 種類の規格が統一され JIS A 6005 (ア スファルトルーフィングフェルト) と改正され現在に至る。

\section{2 防水紙材料の仕様の現状}

木構造の外壁に、ラス下地モルタル塗り仕上げをする場合、防水 紙が、どのような仕様であるのか質問した。質問のうち、防水紙材 料の仕様の施工実態に関するのは、Q3、Q4 である。

表 7 は、Q3 の『外壁ラスモルタルを塗る場合の防水紙仕様』の 調査結果を示す。表 8 はQ4の『防水紙を張る方向』の調査結果を 全国のアンケート調查の割合で示す。表 $7 \cdot 8$ の表頭に示す防水紙の 種類及び方向はアンケート票にあらかじめ選択肢として示し、該当 するものに○を付けてもらっている。

表 7 に示寸防水紙仕様は、以下の通りである。

(1) $8 \mathrm{~kg}$ 巻 $/ 42 \mathrm{~m}$ 厚さ $0.2 \mathrm{~mm}$
JIS や JASS 15 の適用品外である。

(2) $17 \mathrm{~kg}$ 巻 $/ 42 \mathrm{~m}$ ・厚さ $0.5 \mathrm{~mm}$

JIS や JASS 15 の適用品外である。

(3) $20 \mathrm{~kg}$ 巻 $/ 42 \mathrm{~m}$ ・厚さ $0.6 \mathrm{~mm}$

JIS や JASS 15 の適用品。アスファルトフェルト 430 のこと。 (4)ゴムアスファルト系

JIS や JASS 15 の適用品。『改質アスファルトフェルト』と呼ば れるものである。

(5)透湿防水シート

ポリエチレンの不織布で、軽量で透湿性・防水性能は良いが、く ぎ穴シール性が乏しくステープルの穴から水が通るため、JASS 15 では外壁ラス下地モルタルの防水紙としての仕様が示されていない。 透湿防水シートは、釷穴シール性に乏しいので使用不可となってい る。9)

表7 外壁ラスモルタルを塗る場合の防水紙仕様

\begin{tabular}{|c|c|c|c|c|c|c|c|}
\hline & $\begin{array}{l}8 \mathrm{~kg} / \\
42 \mathrm{~m}\end{array}$ & $\begin{array}{l}17 \mathrm{~kg} / \\
42 \mathrm{~m}\end{array}$ & $\begin{array}{l}20 \mathrm{~kg} / \\
42 \mathrm{~m}\end{array}$ & \begin{tabular}{|l} 
改質アスス \\
ファルト \\
フェルト
\end{tabular} & \begin{tabular}{|l|} 
透湿防 \\
水紙
\end{tabular} & \begin{tabular}{|l} 
₹の \\
他
\end{tabular} & 合計 \\
\hline 北海道·東北 & $37.9 \%$ & $41.4 \%$ & $6.9 \%$ & $3.4 \%$ & $10.3 \%$ & $0.0 \%$ & $100.0 \%$ \\
\hline 東京を除く関東 & $14.3 \%$ & $48.1 \%$ & $19.5 \%$ & $3.9 \%$ & $14.3 \%$ & $0.0 \%$ & $100.0 \%$ \\
\hline 甲信越-北陸 & $26.3 \%$ & $42.1 \%$ & $13.2 \%$ & $2.6 \%$ & $7.9 \%$ & $7.9 \%$ & $100.0 \%$ \\
\hline 東海 & $23.8 \%$ & $9.5 \%$ & $33.3 \%$ & $4.8 \%$ & $19.0 \%$ & $9.5 \%$ & $100.0 \%$ \\
\hline 近畿 & $41.7 \%$ & $13.9 \%$ & $11.1 \%$ & $2.8 \%$ & $16.7 \%$ & $13.9 \%$ & $100.0 \%$ \\
\hline 中国-四国 & $36.2 \%$ & $21.3 \%$ & $14.9 \%$ & $0.0 \%$ & $27.7 \%$ & $0.0 \%$ & $100.0 \%$ \\
\hline 九州 & $48.4 \%$ & $19.4 \%$ & $9.7 \%$ & $0.0 \%$ & $19.4 \%$ & $3.2 \%$ & $100.0 \%$ \\
\hline 東京 & $16.7 \%$ & $44.4 \%$ & $27.8 \%$ & $5.6 \%$ & $5.6 \%$ & $0.0 \%$ & $100.0 \%$ \\
\hline 窐国 & $30.7 \%$ & $30.0 \%$ & $177.0 \%$ & $2.9 \%$ & 15.1\% & (4.3\% & $100.0 \%$ \\
\hline
\end{tabular}

表8 防水紙の張る方向

\begin{tabular}{r|r|r|r|l}
\multicolumn{5}{c}{ 表8 防水紙の張る方向 } \\
\hline & 縦張り & 横張り & その他 & 合計 \\
\hline 全国 & $65.0 \%$ & $34.0 \%$ & $1.0 \%$ & $100.0 \%$ \\
\hline
\end{tabular}

表 8 より、防水紙を張る方向は、全国の割合で緃張りが約 64.9\%、

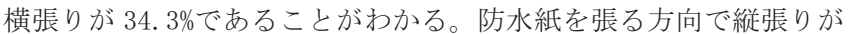
多い理由は、縦張りが『流し張り』と現場で呼ばれ、横張りより施 工性に富んでいることによる。JASS 15 では、防水紙を張る方向は 示されていない。

\section{3 防水紙材料のまとめ}

防水紙の役目は、水の侵入を防ぐ遮水防水効果と、セメントモル タルのアルカリアタックによるラス下地板の劣化の防止とされる。 さらに防水紙はステープル等の締め付け時に発生する破断部分のシ 一ル性およびパッキング性や、侵入した雨水が滞留させないで、早期 に排出する機能が要求される。JASS 15（2007）以後の仕様である住 宅瑕疵担保責任保険・住宅金融支援機構の設計施工基準には、瑕疵 担保履行法の施行に基づき雨漏り対策が明記されており、ここでも 防水紙が $20 \mathrm{~kg} / 1$ 巻を規準としている。 ${ }^{7,8)}$

アンケート結果では、表 7 に示すように、JASS 15 に示されてい ない $8 \mathrm{~kg}$ 巻と $17 \mathrm{~kg}$ 巻の合計は、 $60.7 \%$ であった。JASS 15 に示され ている $20 \mathrm{~kg}$ 巻の 430 は、全国で $17.0 \%$ あった。透湿シートは、中 国・四国地方で $27.7 \%$ と高い比率を示している。

表 7 から判明したことは、JASS 15 に示されている $20 \mathrm{~kg}$ 巻の 430 でなく、適用外の防水紙が全国的に広く用いられていることである。 適用外の防水紙使用の主な要因は、 $20 \mathrm{~kg}$ 巻が、 $8 \mathrm{~kg}$ 巻と $17 \mathrm{~kg}$ と比 較して高価で、質量・厚さが多いため施工性に劣ることであると判 断できる。

著者が参画した共同研究論文の「ラス下地モルタル塗り外壁にお 


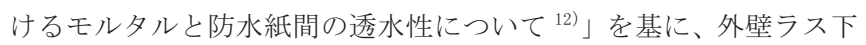
地モルタル塗りにおける漏水が、どのようなことが影響要因となり 得るのか検討した。ここでは、防水紙が構成材料や温熱環境が影響 し易く、特に $8 \mathrm{~kg} /$ 巻のアスファルトフェルトを使用した場合に透水 しやすいことの結果が得られている。さらに現状の $8 \mathrm{~kg}$ 巻及び 17 $\mathrm{kg}$ 巻では、防水効果が $20 \mathrm{~kg}$ 巻に比較して少ないことも明らかになっ ている。12)

\section{5. ラス仕様の調査結果}

\section{1 ラスの変遷}

鉄網(メタルラス) は 1890 年代に、イギリス・アメリカで相次ぎ生 産が始まる。我が国に紹介されたのは、近畿メタルラス工業組合小 冊子によると 1909 年（明治 42 年）であるとされるが、それより 6 年早く 1903 年 (明治 36 年) の大阪での第 5 回勧業博覧会で紹介さ れている。 ${ }^{9)} 1915$ 年（大正 4 年）に、メタルラスである平ラスが、 国産化された。13)

大正・昭和と木骨鉄網壁として鉄網ラスが使用され（表 3) 、戦 時中は物資不足により、臀篻（よしず）が鉄鋼ラスの代用品として 用いられたこともある（表 3）注1)。1949 年（昭和 24 年）頃から戦 後国内建築需要は増大し、さらに防火建築の必要性からメタルラス 業界の夜明けを迎える。

1950 年（昭和 25 年）には、JIS A 5505（メタルラス）が制定さ れた。その他ラスには JIS G 3351 (エキスパンドメタル)、JIS A 5504

(ワイヤラス)、JIS A 5524 (ラスシート) がある。

表 9 は、「左官の知識及彫刻手引」注1) の記述にある臀策壁の工 法を示している。表 3 の表側にあるモルタルから、下塗り、中塗り、

上塗りの工程であったことが読み取れる。

\section{2 ラスの仕様の現状}

木構造の外壁にモルタル塗り仕上げをする場合に、ラスがどのよ うな仕様であるのか質問した。質問のうち、ラスの仕様の施工実態 に関するのは、Q5、Q6 である。

表 9 は、Q5 の外壁ラス下地モルタル塗り仕上げをする場合、ラス 仕様の調查結果を示寸。表 10 は、Q6 のラスの張り方向の調查結果 を表にもとめた全国のラス張り方向の割合を示す。表 $9 \cdot 11$ の表頭 に示すラスの種類及び方向は、アンケート票にあらかじめ選択肢と

して示し、該当するものに○を付けてもらっている。

表 9 から、平ラスが最も一般的に使用されていることがわかる。 ラスを製造する生産工場は、全国的に多くなく、むしろ関東圈、関 西圏に集中している。また、関東と関西では、同じ平ラスや波形ラ スでも JIS 規格品においても、工場での生産設備等によって、種類・ 形状が多少異なる。

表9 外壁ラスモルタルを塗る場合のラスの仕様

\begin{tabular}{r|r|r|r|r|c}
\hline & 平ラス & $\begin{array}{c}700 g \text { 未満 } \\
\text { 波形ラス }\end{array}$ & $\begin{array}{c}\text { 700g以波形ラ } \\
\text { 特殊ラス }\end{array}$ & 合計 \\
\hline 北海道·東北 & $53.8 \%$ & $19.5 \%$ & $0.2 \%$ & $26.5 \%$ & $100.0 \%$ \\
\hline 東京を除く関東 & $30.9 \%$ & $28.2 \%$ & $30.7 \%$ & $10.2 \%$ & $100.0 \%$ \\
\hline 甲信越·北陸 & $80.3 \%$ & $12.8 \%$ & $2.2 \%$ & $4.8 \%$ & $100.0 \%$ \\
\hline 東海 & $69.1 \%$ & $14.7 \%$ & $1.9 \%$ & $14.4 \%$ & $100.0 \%$ \\
\hline 近畿 & $69.3 \%$ & $10.5 \%$ & $0.0 \%$ & $20.2 \%$ & $100.0 \%$ \\
\hline 中国·四国 & $65.9 \%$ & $9.5 \%$ & $0.0 \%$ & $24.6 \%$ & $100.0 \%$ \\
\hline 九州 & $83.8 \%$ & $8.6 \%$ & $0.0 \%$ & $7.7 \%$ & $100.0 \%$ \\
\hline 東京 & $23.1 \%$ & $36.2 \%$ & $33.1 \%$ & $7.7 \%$ & $100.0 \%$ \\
\hline 全国 & $59.5 \%$ & $17.5 \%$ & $8.5 \%$ & $14.5 \%$ & $100.0 \%$ \\
\hline
\end{tabular}

表10 ラスの張り方向

\begin{tabular}{r|r|r|r|l}
\hline & \multicolumn{1}{|c}{ 縦張り } & 横張り & \multicolumn{1}{c}{ その他 } & 合計 \\
\hline 全国 & $66.8 \%$ & $30.9 \%$ & $2.3 \%$ & $100.0 \%$ \\
\hline
\end{tabular}

また、表 10 よりラスを張る方向は、縦張りが全国で約 $66.8 \%$ 、横 張りが 30.9\%であったことがわかる。ラスを張る方向については、 JASS 15 に示されていない。

表 9 に示すラスの仕様は、以下の通りである。

(1)平ラス

JASS 15 の適用品外である。

(2)700 グラム未満波形ラス

JASS 15 の適用品外である。

(2)700 グラム以上波形ラス

JASS 15 の適用品である。

(3)特殊ラス

一部 JASS 15 の適用品になる。複合ラス類と呼ばれるものも販売 されている。

\section{3 ラス生産者に対する各種ラス生産量等のアンケート調査}

今回の調査と同時期に、近畿メタルラス工業会・関東メタルラス 工業会に加盟するラス製造業者に対してもアンケート調査を行った。 表 11 は『各種ラスの年間生産量は?。』という質問に対する回答 を示す。発送数、回答数は、以下の通りである。

近畿メタルラスへの発送数: 17 通（回答数 7 通）

関東メタルラスへの発送数：5通（回答数 4 通）

回答された東京の 2 社は，木造外壁のラスは生産していない。

表 11 に記す 6 種類のラスは調査表に示したものであり、生産量 は得られた回答を基に集計したものである。全国で $42.6 \%$ と平ラス の生産量が $40 \%$ に至っており、平ラスの需要が多いことが、ラス生 産者側のアンケート調査からも判断できる。

表11 各種ラスの年間生産量, 生産割合（全国）

\begin{tabular}{l|r|r|r|r|r|r|c}
\hline & 平ラス & $\begin{array}{c}\text { 波形ラ } \\
\text { ス }\end{array}$ & リブラス & $\begin{array}{c}\text { 特殊ラ } \\
\text { ス }\end{array}$ & $\begin{array}{c}\text { ラスシー } \\
\text { ト }\end{array}$ & $\begin{array}{c}\text { 鉄線・溶 } \\
\text { 接鉄網 }\end{array}$ & 計 \\
\hline $\begin{array}{l}\text { 生産量量 } \\
(\text { 自 }\end{array}$ & 9384.5 & 4237.3 & 2240.0 & 5585.2 & 25.0 & 550.0 & 22022.0 \\
\hline $\begin{array}{l}\text { 年産割合 } \\
\text { (\%) }\end{array}$ & $42.6 \%$ & $19.2 \%$ & $10.1 \%$ & $25.4 \%$ & $0.1 \%$ & $2.5 \%$ & $100.0 \%$ \\
\hline
\end{tabular}

\section{4 ラス材料のまとめ}

近畿、中国、四国、九州では、JASS 15 に示されている波形ラス 1 号等で $700 \mathrm{~g} / \mathrm{m}^{2}$ 以上を使用している、という回答が無かった。 JASS 15 に示されている波形 1 号は、全国で $8.5 \%$ と使用率が 1 割に 満たない。また、同じ波形でも量目不足の $700 \mathrm{~g} / \mathrm{m}^{2}$ 以下のものが、 17. $5 \%$ と JASS 15 仕様のものより使用率が高い。特に平ラスは、全 国平均で $59.5 \%$ 、と高い比率を示す。東京地区において平ラスの使用 割合は $23 \%$ あるが、関東より西の地域である東海、甲信越・北陸、 近畿、中国・四国、九州では、66\%〜84\%の大きい割合になった。

波形ラスより平ラスが多く用いられてきた理由は、平ラスの施工 性が良いことにある。さらに、ラス系下地に用いたセメントモルタ ル塗りの平面精度は、波形ラスより平ラスの方が確保しやすい。

ラスの規準は JASS 15 M-101の「ラス系下地用鋼製金網下地の 品質規準」にある。規準とされる波形 1 号ラスの質量 $700 \mathrm{~g} / \mathrm{m}^{2}$ は、 
モルタルの厚さを $20 \mathrm{~mm}$ 、引張強度を $2.0 \mathrm{~N} / \mathrm{mm}^{2}$ とし、金網の強度 を $400 \mathrm{~N} / \mathrm{mm}^{2}$ という仮定の下で、モルタルがひび割れたとき、ひび 割れ前のモルタルに働いた応力を鋼製金網が分担できる最低の值 である。 ${ }^{14)}$ JASS 15 M-101 の基準とする波形 1 号ラスが用いられ るように、早急の改善が望まれる。

\section{6. ステープル（留め付け金具）の変遷と仕様の調査結果 6.1 ステープルの変遷}

1952 年 (昭和 27 年) に、文房具としてホッチキスが発売される。 1958 年（昭和 33 年）には、ホッチキスの針を使用し、画鋲代わり にポスターなどを張る事務機としてガンタッカが販売開始された。 しかし、ガンタッカは事務用として普及せず、モルタル塗りのラス 張り用として利用されるようになる。注 3

ステープルは JASS 15 M-105 の「ラス系下地用ステープルの品 質規準」にあり、ここで定められた耐食性の評価は JIS Z 2371 に よる塩水噴霧試験によって 6 時間で外側に赤錆がないこととされ ている ${ }^{15)}$ 。現在の JIS A 5556「工業用ステープル」では、メッキ 処理に関する規定がなく、耐食性の試験方法は、文房具用ステー プルと同等レベルで評価されている。文具と外壁とでは大きく環 境が異なり、外壁に使用寸るステープルの評価規準は、溶融亜鉛 メッキ処理されたものや、ステンレス等の改訂が必要とされる。

\section{2 ステープルの仕様の現状}

ステープルは、地震時に変形、回転、移動する構造体とモルタル をつなぎ留める重要な接合材である。木構造の外壁にモルタル塗り 仕上げをする場合に、ステープルが、どのような仕様であるのか質 問した。調査の質問のうち、ステープルの仕様に関するのは、Q7、 Q8 である。

表 12 は、Q7 の『ステープル（留め付け金具）の仕様』の調査結 果を示す。表 13 は、Q8 の『ステープルの間隔寸法』の調査結果を 示す。

表12 ステープルと留め付け工具の仕様

\begin{tabular}{r|r|r|r|r|r|r|l}
\hline & $\begin{array}{c}\text { ハンマー } \\
10 \mathrm{~mm}\end{array}$ & $\begin{array}{c}\text { ハンマー } \\
13 \mathrm{~mm}\end{array}$ & $\begin{array}{c}\text { 機械 } \\
13 \mathrm{~mm}\end{array}$ & $\begin{array}{c}\text { 機械 } \\
16 \mathrm{~mm}\end{array}$ & $\begin{array}{c}\text { 機械 } \\
19 \mathrm{~mm}\end{array}$ & その他 & 計 \\
\hline 北海道·東北 & $25.9 \%$ & $16.1 \%$ & $18.2 \%$ & $15.0 \%$ & $24.8 \%$ & $0.0 \%$ & $100.0 \%$ \\
\hline 東京を除く関東 & $7.9 \%$ & $10.5 \%$ & $41.0 \%$ & $25.1 \%$ & $12.2 \%$ & $3.4 \%$ & $100.0 \%$ \\
\hline 甲信越·北陸 & $27.7 \%$ & $16.5 \%$ & $27.8 \%$ & $13.8 \%$ & $8.4 \%$ & $5.9 \%$ & $100.0 \%$ \\
\hline 東海 & $33.3 \%$ & $0.6 \%$ & $28.4 \%$ & $26.2 \%$ & $11.5 \%$ & $0.0 \%$ & $100.0 \%$ \\
\hline 近畿 & $35.5 \%$ & $25.2 \%$ & $14.1 \%$ & $15.4 \%$ & $9.8 \%$ & $0.0 \%$ & $100.0 \%$ \\
\hline 中国·四国 & $40.5 \%$ & $13.3 \%$ & $22.0 \%$ & $10.8 \%$ & $13.5 \%$ & $0.0 \%$ & $100.0 \%$ \\
\hline 九州 & $54.7 \%$ & $14.0 \%$ & $13.2 \%$ & $9.3 \%$ & $8.0 \%$ & $0.8 \%$ & $100.0 \%$ \\
\hline 東京 & $4.4 \%$ & $2.3 \%$ & $38.9 \%$ & $30.0 \%$ & $18.2 \%$ & $6.2 \%$ & $100.0 \%$ \\
\hline 全国 & $28.7 \%$ & $12.3 \%$ & $25.5 \%$ & $18.2 \%$ & $13.3 \%$ & $2.0 \%$ & $100.0 \%$ \\
\hline
\end{tabular}

表頭にある10mm、13mm、15mm、19mmの数字は足の長さを示す。

表13 ステープルの間隔寸法

\begin{tabular}{r|r|r|r|r|r|r}
\hline & $70 \mathrm{~mm}$ 以内 & $71 \sim 100$ & $101 \sim$ & $151 \sim$ & $201 \mathrm{~mm}$ 以上 & \\
\hline 北海道·東北 & $23.8 \%$ & $33.3 \%$ & $33.3 \%$ & $9.5 \%$ & $0.0 \%$ & $100.0 \%$ \\
\hline 京を除く関東 & $21.0 \%$ & $40.3 \%$ & $33.9 \%$ & $4.8 \%$ & $0.0 \%$ & $100.0 \%$ \\
\hline 甲信越·北陸 & $13.3 \%$ & $53.3 \%$ & $26.7 \%$ & $6.7 \%$ & $0.0 \%$ & $100.0 \%$ \\
\hline 東海 & $21.1 \%$ & $47.4 \%$ & $31.6 \%$ & $0.0 \%$ & $0.0 \%$ & $100.0 \%$ \\
\hline 近畿 & $30.0 \%$ & $30.0 \%$ & $30.0 \%$ & $3.3 \%$ & $6.7 \%$ & $100.0 \%$ \\
\hline 中国·四国 & $33.3 \%$ & $33.3 \%$ & $33.3 \%$ & $0.0 \%$ & $0.0 \%$ & $100.0 \%$ \\
\hline 九州 & $34.6 \%$ & $19.2 \%$ & $38.5 \%$ & $7.7 \%$ & $0.0 \%$ & $100.0 \%$ \\
\hline 東京 & $13.3 \%$ & $40.0 \%$ & $40.0 \%$ & $6.7 \%$ & $0.0 \%$ & $100.0 \%$ \\
\hline 全国 & $23.8 \%$ & $37.1 \%$ & $33.4 \%$ & $4.9 \%$ & $0.8 \%$ & $100.0 \%$ \\
\hline
\end{tabular}

表 12 の表頭に示す留め付け工具とステープルの長さで示す種類 の組み合わせ、及び、表 13 の表頭に示すステープルの間隔寸法は、 アンケート票にあらかじめ選択肢として示し、該当するものに○を 付けてもらっている。

\section{3 ステープルのまとめ}

表 12 から、以下のことがわかる。まず、表頭にある足の長さ $19 \mathrm{~mm}$ 以上のステープルの使用割合は、全国で $13.3 \% 、 13 \mathrm{~mm}$ で $37.8 \% 、 10 \mathrm{~mm}$ で $28.7 \%$ でった。足の長さ $16 \mathrm{~mm}$ 以上のステープルは、手打ちの八 ンマータッカーで留め付けることが不可能であり、コンプレッサー と機械を用意する必要がある。また、足の長さ $13 \mathrm{~mm}$ と $16 \mathrm{~mm}$ のステ ープルは、機械打ちとしている業者が多い。肩幅 $12 \mathrm{~mm}$ で足長 $13 \mathrm{~mm}$ の手打ちであるが、多くが足の長さ $10 \mathrm{~mm}$ の手打ち式で留め付けてい るのが現状である。

表 14 から、ステープルの留め付け間隔は、JASS 15 に示される 100 mm以内としているものが多く、全国で $60.9 \%$ であることがわかる。 ステープルの留め付け間隔が密なほど、また脚長が長いほど耐力が 高いという実験結果が得られている。占今回の調查で、足の長さ $19 \mathrm{~mm}$ 以上のステープルが、何れの地域においても 8～25\%の範囲にあっ た。アンケート結果にある、機械打ちとする足の長さ $19 \mathrm{~mm}$ のステ ープルが使用されない理由は、コンプレッサー等の設備投資や現場 でのホースの取り回しのわずらわしさであるとされる ${ }^{6)}$

ステープルの機能として保持力が要求されるが、筆者が参画し た共同研究での実験結果によれば、保持力の值の結果はアンケー 卜調查で一番多く用いられた 1210F が、JASS 15 の規準品 1019J の $1 / 2$ 程度であった ${ }^{5)}$ 。規準に満たないステープルを使用した外 壁ラス下地モルタル塗り仕上げは、地震時に剥離・剥落を懸念さ れることから、JASS 15 に示された 1019J ステープルの使用が望ま れる。

\section{7. ラス下地用セメントモルタルの現状}

\section{1 ラス下地用セメントモルタルの変遷}

1970 年（昭和 45）代には、コンクリート用既調合材料が販売され ていたが、木造のラス下地用セメントモルタルが開発・販売された のは、1985 年（昭和 60 年）であった。ラス下地用セメントモルタ ルは、15 年に渡って市場に姿を見せなかったが、1983 年（昭和 58 年）に、主骨材となる発泡樹脂破砕粒が開発・販売され、これによ って各社開発・販売の数量を伸ばしてきた。

1989 年 (平成元年) には、「JASS 15M-105 既調合軽量セメントモ ルタルの品質規準」が制定され、2006 年 (平成 18 年) には、JASS 15 改訂に伴い「JASS 15M-105 ラス下地用既調合軽量セメントモルタル の品質規準」に至るが、JIS は制定化されていない。

表 14 は、1992 年（平成 4 年）から 2008 年（平成 20 年）のラス 下地用既調合軽量セメントモルタルの生産数量を示す。

ラス下地用既調合軽量セメントモルタルの生産量は 1995 年をピ ークに、減少してきたが、2002 年頃から、ラス下地セメントモルタ ル仕上げが見直され 2006 年には過去最高の生産量となった ${ }^{16)} 。$ 
表14 ラス下地用既調合軽量セメントモルタ ルの生産量 (t) NSK調べ ${ }^{16)}$

\begin{tabular}{l|r}
\hline 1993年 & 141,267 \\
\hline 1994年 & 159,691 \\
\hline 1995年 & 209,597 \\
\hline 1996年 & 202,166 \\
\hline 1997年 & 177,985 \\
\hline 1998年 & 132,845 \\
\hline 1999年 & 137,845 \\
\hline
\end{tabular}

\begin{tabular}{l|r}
\hline 2001年 & 135,390 \\
\hline 2002年 & 165,428 \\
\hline 2003年 & 180,826 \\
\hline 2004年 & 198,823 \\
\hline 2005 年 & 218,766 \\
\hline 2006年 & 234,257 \\
\hline 2007年 & 197,960 \\
\hline
\end{tabular}

\section{2 ラス下地用セメントモルタルの現状}

木構造の外壁にモルタル塗り仕上げをする場合の、ラス下地用セ メントモルタルの仕様について質問した。質問のうち、ラス下地用 セメントモルタルの施工実態に関するのは、Q9 である。

表 15 は、Q9 の『ラス下地用に用いるセメントモルタルの仕様』 の調査結果を示す。表 15 にあるセメントと骨材の種類と組み合わせ の 4 項目は、アンケート票にあらかじめ選択肢として示し、該当す るものに○を付けてもらっている。表 15 にある、軽量モルタルと現 場調合モルタルの材料の概要を、(1)〜 (2)に示す。

(1)軽量モルタル

JASS 15M-102 ラス系下地用既調合セメントモルタルの品質規 準に基づくもの。

(2)現場調合モルタル

セメント、骨材（砂もしくは左官用軽量発泡骨材）、水、混和材 料などを現場で調合したもの。

表15 ラス下地用に用いるセメントモルタルの仕様

\begin{tabular}{|c|c|c|c|c|c|}
\hline & 軽量十軽量 & \begin{tabular}{|l} 
現場調合+ \\
現場調合
\end{tabular} & $\begin{array}{l}\text { 現場調合+ } \\
\text { 軽量 }\end{array}$ & $\mid \begin{array}{l}\text { 軽量+現 } \\
\text { 場調合 }\end{array}$ & 合計 \\
\hline 北海道·東北 & $37.5 \%$ & $52.0 \%$ & $10.5 \%$ & $0.0 \%$ & $100.0 \%$ \\
\hline 東京を除く関東 & $69.7 \%$ & $13.1 \%$ & $17.2 \%$ & $0.0 \%$ & $100.0 \%$ \\
\hline 甲信越·北陸 & $19.5 \%$ & $59.0 \%$ & $18.2 \%$ & $3.3 \%$ & $100.0 \%$ \\
\hline 東海 & $71.2 \%$ & $15.9 \%$ & $12.9 \%$ & $0.0 \%$ & $100.0 \%$ \\
\hline 近畿 & $67.6 \%$ & $21.6 \%$ & $8.4 \%$ & $2.4 \%$ & $100.0 \%$ \\
\hline 中国·四国 & $42.7 \%$ & $47.8 \%$ & $12.2 \%$ & $0.0 \%$ & $100.0 \%$ \\
\hline 九州 & $18.4 \%$ & $67.9 \%$ & $10.8 \%$ & $2.9 \%$ & $100.0 \%$ \\
\hline 東京 & $76.4 \%$ & $8.2 \%$ & $15.4 \%$ & $0.0 \%$ & $100.0 \%$ \\
\hline 全国 & $50.3 \%$ & $35.6 \%$ & $13.1 \%$ & $1.0 \%$ & $100.0 \%$ \\
\hline
\end{tabular}

\section{3 ラス下地用セメントモルタルのまとめ}

表 15 から以下のことがわかる。下塗りと上塗りに現場調合モルタ ルのみを使用する割合は、全国で 35.6\%、既調合軽量モルタルのみは 50.3\%、現場調合モルタルと軽量モルタルの併用は $14.1 \%$ あっった。 何れの地区も、上塗りと下塗りのモルタルの種類を変えないで使用 している割合が多く、79～90\%の範囲となった。また、既調合軽量モ ルタルの使用割合は、地域による差が著しく、東京で $76 \%$ 、九州で $18 \%$ となり、都市部での割合が多い。現場調合モルタルは、北海道・東 北、甲信越・北陸、九州で $50 \%$ 以上を占めている。都市部で自然砂 が使用されない理由は、良好な自然砂の供給が充分でないことと、 捏ね場が狭小なため左官材料の置き場に笨していることがあげられ る。

軽量化が一般化する中、現場調合モルタルに信頼やこだわりを持 つ左官事業所が多いことが、調査より読み取れる。また、調査より、 既調合軽量モルタルは普及していない地域が多いことが分かった。

\section{8. 施工実態と仕様書との乘離のまとめ}

外壁ラス下地モルタル仕上げの施工実態と JASS15 との乘離の現 状を表 16 に示した。表 16 の表頭には、アンケート調査で一番多く 使用されたもの、JASS 15 および住宅瑕疪担保責任保険法人の全て の法人で統一された「住宅瑕疵担保責任保険 設計施工基準」による 仕様に関してそれぞれ示した。表側には、外壁ラス下地モルタル仕 上げに用いられる材料・部材をそれぞれ示した。

表16 アンケート実態調査結果と仕様書との乘離の現状

\begin{tabular}{|c|c|c|c|}
\hline & $\begin{array}{l}\text { アンケート調査で一番多 } \\
\text { く用いられたも。 }\end{array}$ & JASS 15の仕様 & $\begin{array}{l}\text { 厂住宅瑕疵担保責任 } \\
\text { 保険設計基準」の仕 } \\
\text { 様 }\end{array}$ \\
\hline 下地板 & ラス下地板 $12 \mathrm{~mm} \times 75 \mathrm{~mm}$ & $\begin{array}{l}\text { ラス下地板 } 12 \mathrm{~mm} \times 75 \\
\mathrm{~mm}\end{array}$ & \\
\hline 防水紙 & $\begin{array}{l}\text { アスファルトフェルト } 8 \mathrm{~kg} \\
/ 1 \text { 巻 }\end{array}$ & $\begin{array}{l}\text { アスファルトフェル } \\
\text { ト430: } 20 \mathrm{~kg} / \text { 巻き }\end{array}$ & JASS 15に準ずる \\
\hline ラス & 平ラス & 波形 1号ラス & JASS 15に準ずる \\
\hline ステープル & $1210 \mathrm{~F}$ & $1019 \mathrm{~J}$ & JASS 15に準ずる \\
\hline $\begin{array}{l}\text { セメントモ } \\
\text { ルタル }\end{array}$ & $\begin{array}{l}\text { 現場調合・既調合モルタ } \\
\text { ルはほぼ同率である。 }\end{array}$ & $\begin{array}{l}\text { 現場調合・既調合モ } \\
\text { ルタル }\end{array}$ & JASS 15に準ずる \\
\hline
\end{tabular}

表 16 からは、ラス下地板およびセメントモルタルの使用材料の 施工実態が JASS 15 の水準を満たしており、防水紙、ラス、ステー プルの実態が、JASS 15 の仕様を満たしていないものであることを 確認することができた。また、ここでは、施工実態と JASS15 を含 む仕様書との乘離を解消しなければならないことを確認することが できた。

\section{9. 施工実態と仕様書の乘離の解消について}

表 16 に示すように、「住宅瑕疪担保責任保険設計基準」の仕様書 では、防水紙、ラス、ステープルの仕様が JASS 15 に準じている。 すべての保険法人は「住宅瑕疵担保責任保険設計基準」の仕様とと もに、それに基づく現場検査業務を実施している。この現場検査業 務を適切に実施することが、施工実態と仕様書の乘離を解消する有 力な方策の一つである。

\section{0. 結論}

本研究により、外壁ラス下地モルタル塗り仕上げは、現在につな がる左官壁の構法で紹介している文献に基づき、幕末までさかのぼ り、価格・作業性を優先して選択され、現在に至っていることが分 かった。

アンケート調査からは平ラス・防水紙・ステープルの現状が、JASS 15 の仕様に示されている水準に満たないものであることを確認で きた。現在の施工実態と JASS 15 を含む仕様書の乘離の実態を解消 することにより、外壁ラス下地モルタル塗り仕上げの一層の普及に つながることが期待できる。

\section{謝辞}

本研究のアンケート調查と各材料・部材の実験結果は、国土交通省 国土技術政策総合研究所が、日本左官業組合連合会、関東メタルラ ス工業組合、近畿メタルラス工業組合、全日本外壁ピンネット工事 業協同組合の 4 団体と共同研究を締結し研究した成果の一部であ る。また工学院大学工学部建築学科吉田研究室の卒論生・大学院生 の皆様に多大な御協力を頂いた。ここに記して関係各位に深く謝 
意を表す。

\section{参考文献}

1）日本建築学会編：建築工事標準仕様書 - 同解説 JASS 15 左官工事、 pp147-160、2007.6

2）難波蓮太郎：木造住宅のモルタル外壁被災調査及び而震・防火性能改善 に関する研究、工学院大学総合研究所年報、第 1 号、pp175-199、 1995. 7

3） 木造住宅実大振動実験委員会 : 第 5 編ラスモルタル外壁振動実験、木造 住宅実大振動実験報告書、（財）日本住宅・木造技術センター、1996.10

4）宮村雅史、鈴木 光、山中豊茂、西山栄一、横田裕司 : ラス下地モルタル 叙り工法に関する調査研究（その 1 ）、日本建築学会大会学術講演梗概 集、C-1 分冊、pp269-270、2006.9

5）鈴木 光、宮村雅史、山中豊茂、西山栄一、横田裕司：ラス下地モルタル 塗り工法に関寸る調查研究（その 2 ）、日本建築学会大会学術講演梗概 集、C-1 分冊、pp271-272、2006.9

6）鈴木光、古賀一八、山中豊茂、近藤敏：平成 16 年新潟県中越地震にお ける湿式外壁被害調査その 2 ラスモルタル及び土壁の被害調査、日本建 築学会大会学術講演梗概集、A-1 分冊、pp241-242、2005.9

7）独立行政法人住宅金融支援機構：木造住宅工事仕様書 平成 22 年改訂 （全国）、pp157-167、2010

8）財団法人住宅保証機構：住宅瑕疵担保責任保険設計基淮 平成 21 年度 版、p4、2009.10

9）難波蓮太郎：土物・漆喰からポルトランドセメントへ(豆知識）、コンク リート工学、pp61-68、2002。3
10）日本建築学会編：建築工事標準仕様書 - 同解説 JASS 11 木工事 pp131-156、2005. 11

11）日新工業(侏)：アスファルトルーフィングのルーツを探ねて、日新工業(株 40 周年記念誌、pp59〜62、1984.9

12）宮村雅史、鈴木 光、古賀一八、石川廣三、山㠃 肇、西田和生：ラス下 地モルタル塗り外壁におけるモルタルと防水紙間の透水性について、日 本建築学会大会学術講演梗概集、C-1 分冊、pp269-270、2009.9

13）若島健一、真鍋恒博、池田真啓：我が国における左官壁構法の変遷、日 本建築学会大会学術講演梗概集、E-1 分冊、pp629-630、1999.9

14）日本建築学会編: 建築工事標準仕様書・同解説 JASS 15 左官工事、JASS 15 M-101のラス系下地用鋼製金網下地の品質規準、pp318-320、2007.6

15）日本建築学会編: 建築工事標準仕様書・同解説 JASS 15 左官工事、JASS $15 \mathrm{M}-105$ のラス系下地用ステープルの品質規準、pp147-160、2007.6

16）原田進：ラスモルタル用既調合軽量セメントモルタルの基調と展望、 建築仕上年鑑、工文社、pp66-67、2009.11

\section{注}

注 1) 中西由造著「左官の知識及彫刻手引」、戦前の左官教科書として吉田工 務所出版部より昭和 5 年発刊、中西氏は東京府立実科工業学校左官科 教師として活躍

注 2)「プラスター誌」東京左官工業組合の機関誌として大正 10 年発刊、昭 和 18 年休刊、戦後の「日左連」誌の前身として評価される。

注 3)木田 捷氏にご教授 日本自動釘打機ステープル工業会所属

（2010年 7 月 8 日原稿受理，2010年11月 22 日採用決定） 